\title{
A functional mutation at position -155 in porcine APOE promoter affects gene expression
}

Shixin $\mathrm{Li}^{2,4+}$, Hao Zhang ${ }^{1,2+}$, Ping Gao ${ }^{1,3}$, Zanmou Chen ${ }^{1}$, Chong Wang ${ }^{1,2}$ and Jiaqi $\mathrm{Li}^{1,2^{*}}$

\begin{abstract}
Background: Apolipoprotein E, a component of the plasma lipoproteins, plays an important role in the transport and metabolism of cholesterol and other lipids. Three single nucleotide polymorphisms (SNPs) $-491 \mathrm{~A}>\mathrm{T},-219 T>\mathrm{G}$ and $+113 G>C$ in the regulatory region of human apolipoprotein $E$ gene (APOE) change the promoter activity and are associated with a wide variety of disorders including Alzheimer disease (AD). Functional SNPs in porcine APOE gene $5^{\prime}$ regulatory region have not been explored.

Results: We examined SNPs within this region (from -831 to +855 ), and the analysis revealed that the T>A SNP at position -155 among these three polymorphism sites $(-440,-155,+501)$ was found to exert a marked influence on the transcription of the porcine $A P O E$ gene. Electrophoretic mobility shift assays showed that the binding affinity of oligonucletides containing the $-155 \mathrm{~A}$ to transcription factor(s) was stronger than that of the -155T. Transient transfection assays and quantitative real-time PCR results revealed that the $-155 T>A$ variant enhanced the activity of the APOE promoter and was associated with increased APOE mRNA levels in vivo.

Conclusions: These data suggest that the $-155 T>A$ mutation in the promoter region of the porcine APOE gene is an important functional variant. The results provided new insights into aspects of pig genetics and might also facilitate the application of pigs in biomedical studies addressing important human diseases.
\end{abstract}

\section{Background}

Apolipoprotein $\mathrm{E}(\mathrm{apoE}=$ protein; $A P O E=$ gene $)$ is a component of lipoproteins, and thereby regulates lipoprotein metabolism; apoE also plays a key role in maintaining neuronal integrity [1-4]. Utermann et al. [5] were the first to identify three isoforms of human apoE, named E2, E3, and E4. The allele encoding apoE4 is a risk factor for atherosclerosis [6,7], and $\mathrm{AD}[1,8,9]$. In addition, humans with E4 allele responded to a lipidlowering therapy poorly whereas those with E2 allele sensitively [10]. There are four single nucleotide polymorphisms (SNPs) at $-491,-427,-219$ and +113 in human $A P O E$ promoter [11-13]. The base substitutions at $-491 \mathrm{~A}>\mathrm{T}$ and $-219 \mathrm{~T}>\mathrm{G}$ were found to alter promoter activity and transcription factor binding affinity $[12,14,15]$. The $-491 \mathrm{SNP}$ and $-219 \mathrm{SNP}$ were related to different plasma apoE [16], LDL and cholesterol

\footnotetext{
* Correspondence: jali@scau.edu.cn

† Contributed equally

'Guangdong Provincial Key Lab of Agroanimal Genomics and Molecular Breeding, College of Animal Science, South China Agricultural University, Guangzhou 510642, Guangdong, PR China

Full list of author information is available at the end of the article
}

concentrations [17], and the risks of atherosclerosis [16] and AD [14,15]. Furthermore, +113SNP modulated lipid, lipoprotein concentrations and aortic atherosclerosis $[11,13]$. However, there were inconsistent reports about $A P O E$ polymorphisms and coronary heart disease [18] or AD [19-21].

In pigs, $A P O E$ has been mapped to chromosome 6 $[22,23]$. Porcine $A P O E$ is 4267 nucleotides in length, comprising of four exons and three introns, and a (CG) 13 microsatellite located within intron 3 [24]. Additionally, Brzozoeska et al. [25] studied the cDNA sequence of porcine $A P O E$, and Kurył [23] described three isoforms of porcine apoE. Fan et al. [26] recently demonstrated that a SNP within intron 2 of porcine $A P O E$ was associated with body conformation traits. However, the functional SNPs in the 5' regulatory region of porcine $A P O E$ remain unclear.

To identify the functional SNPs in the 5' regulatory region of porcine $A P O E$, mRNA expression levels and promoter activities associated with different genotypes were analyzed with quantitative RT-PCR (qRT-PCR) and transient transfection assays respectively, potential cis-acting 
elements surrounding the SNP were examined with electrophoretic mobility shift assays (EMSAs). Our results indicate that the -155 SNP modulates the expression level of porcine $A P O E$.

\section{Results}

Screening for SNPs in the APOE $5^{\prime}$ regulatory region

Three overlapping fragments from -831 to +855 (1686 bp) were amplified. Three SNPs were identified in this region: $-155 \mathrm{~T}>\mathrm{A},-440 \mathrm{G}>\mathrm{A}$, and $+501 \mathrm{~A}>\mathrm{T}$.

\section{A SNP", 1,0,1,0,0pc,0pc,0pc,0pc>Genotype frequencies of $-155 T>A$ SNP}

The genotypic frequencies of -155SNP were listed in Table 1 . The frequencies were highly significant among different genotypes within the breeds $(P<0.01)$, but not significantly different $(P>0.05)$ between the breeds.

\section{Alternations of predicted transcription factor binding sites surrounding porcine APOE SNPs}

The three polymorphic sites were examined with MatInspector http://www.genomatix.de[27]. Results revealed that the mutation $-155 \mathrm{~T}>\mathrm{A}$ lost the transcription factor sites for GAGA, KLF6, PUR $\alpha$, KKLF, cKROX and MAZ, and gained sites for BKLF and CTCF (additional file 1), while the other two $(-440 \mathrm{G}>\mathrm{A}$, and $+501 \mathrm{~A}>\mathrm{T})$ did not show changes (data not shown).

\section{Alignment of porcine and human APOE promoter sequences}

We aligned porcine and human $A P O E$ promoter sequences. The homology of the proximal promoter regions between human $A P O E$ from -236 to +10 and porcine $A P O E$ from -265 to -12 was of greater similarity (69.1\%) than those of -266 or more upstream of porcine $A P O E$, and a TATA box was found in the two sequences (Figure 1), which suggested functional importance of these fragments across the two species. There is a functional mutation $-219 \mathrm{~T}>\mathrm{G}$ in human $A P O E$ [12], and the $-155 \mathrm{~T}>\mathrm{A}$ of porcine $A P O E$ changes the potential transcription factor binding sites (additional file 1). Thus $-155 \mathrm{~T}>\mathrm{A}$ mutation was further studied.

Table 1 Genotype frequencies of the porcine APOE -155 SNP in different populations.

\begin{tabular}{lcccc}
\hline Breed & N & \multicolumn{3}{c}{ Genotype } \\
\cline { 3 - 5 } & & TT & TA & AA \\
Dahuabai & 58 & $20(0.34)$ & $30(0.52)$ & $8(0.14)$ \\
Lantang & 50 & $22(.44)$ & $24(0.48)$ & $4(0.08)$ \\
Yorkshire & 51 & $26(0.51)$ & $19(0.37)$ & $6(0.12)$ \\
Landrace & 50 & $24(0.48)$ & $25(0.50)$ & $1(0.02)$ \\
\hline
\end{tabular}

$\mathrm{N}$, Number of animals.

\begin{tabular}{|c|c|c|}
\hline Human & -236 & 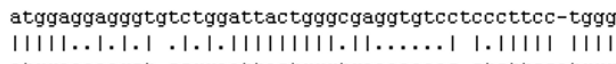 \\
\hline Pig & -265 & atggaaaaagct-ccggaattactgggtgaaaaaac-ctcttccatggg \\
\hline Human & -187 & 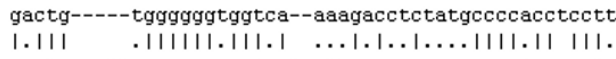 \\
\hline Pig & -217 & ggctggaattagggggggggtgatggttgccaaccccaccctcc-cctc \\
\hline Human & -144 & 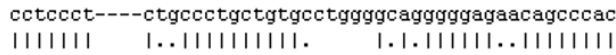 \\
\hline Pig & -168 & $\begin{array}{c}\text { cctcccttccccaccctgctgtgt-----gaaaggggaggccagcccac } \\
-\mathbf{1 5 5}\end{array}$ \\
\hline Human & -98 & 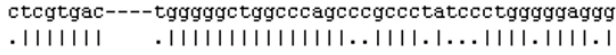 \\
\hline Pig & -123 & ttcgtgacccgacgg \\
\hline Human & -52 & 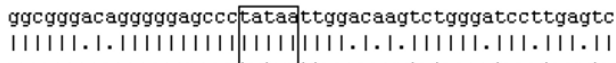 \\
\hline Pig & -73 & ggcggggcggggggagccctatasttggccgaatctgggctccctgaatc \\
\hline Human & & $\begin{array}{ll}\operatorname{cccc} \\
1111\end{array}$ \\
\hline & & \\
\hline \multicolumn{3}{|c|}{$\begin{array}{l}\text { Figure } 1 \text { Homology of human } A P O E \text { and porcine } A P O E \\
\text { promoter. The porcine promoter sequence }(225 \mathrm{bp})(\mathrm{U} 70240.1) \text { was } \\
\text { aligned with the proximal-most } 245 \text { bp of human APOE sequence } \\
\text { (AF261279). The similarity is } 69.1 \% \text {. Positions of the "TATA" box and } \\
\text { the }-155 \mathrm{SNP} \text { site are indicated. }\end{array}$} \\
\hline
\end{tabular}

Effects of -155 mutation on APOE mRNA levels

To determine whether $-155 \mathrm{~T}>\mathrm{A}$ was associated with differential APOE expression in vivo, hepatic mRNA levels of adult Dahuabai pigs were analyzed with qRT-PCR. The results revealed that mRNA levels of -155AA animals were approximately 11 times higher than those of -155TT animals (Figure 2).

\section{The -155SNP effects on $A P O E$ transcription}

We used the porcine $A P O E$ promoter region spanning -268 to -11 to assemble fusion constructs of the $A P O E$ promoter and a firefly luciferase reporter. As shown in Figure 3, the promoter with $-155 \mathrm{~A}$ allele was significantly better at driving luciferase expression, and reporter levels were 6.7-time higher than that with $-155 \mathrm{~T}$.

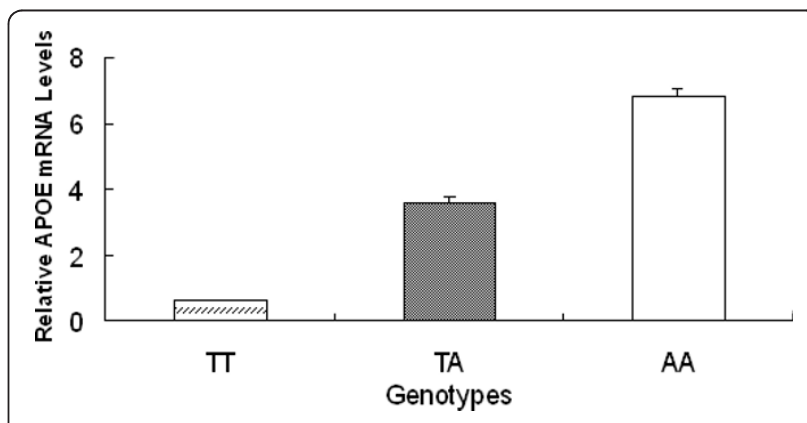

Figure 2 The $T>A$ transition at position -155 in the porcine $A P O E$ promoter region increases mRNA levels in Dahuabai pigs. Data are expressed as means \pm S.E.. The mRNA levels of different genotypes differ $P<0.01$. 


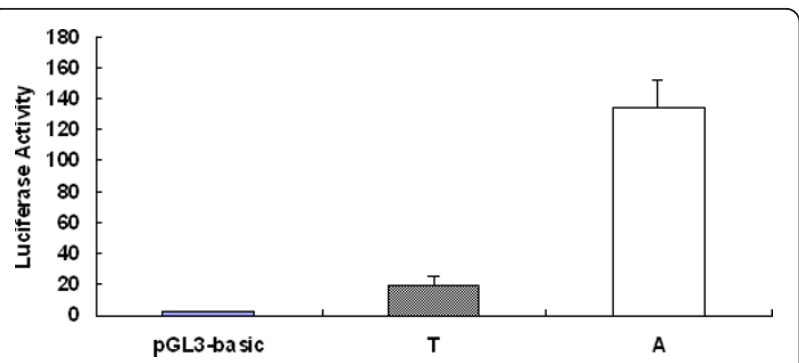

Figure 3 Functional analysis of porcine $A P O E$ promoter alleles containing -155T or A. Data are expressed as means \pm S.E.. The activity of the $-155 \mathrm{~A}$ promoter is significantly $(P<0.01)$ higher than that of $-155 T$.

\section{A mutation on DNA-protein interactions", 1,0,1,0,0pc,0pc,0pc,0pc>Impact of the -155T>A mutation on DNA-protein interactions}

EMSAs were performed to understand whether the differential promoter activities were related to changes in protein binding. As shown in Figure 4, incubation of nuclear extract with the probe corresponding to the $-155 \mathrm{~T}$ or $-155 \mathrm{~A}$ allele predominantly formed a specific binding complex (lane 2 of Figure $4 \mathrm{~A}$ and $4 \mathrm{~B}$, arrowed). The binding complex of $-155 \mathrm{~T}$ probe with transcriptional factor(s) was largely abolished by co-incubation with an excess of either unlabelled $-155 \mathrm{~T}$ or $-155 \mathrm{~A}$ allele probes (lanes 3-6 of Figure 4A). By contrast, the complex formed by incubation of nuclear extract with the

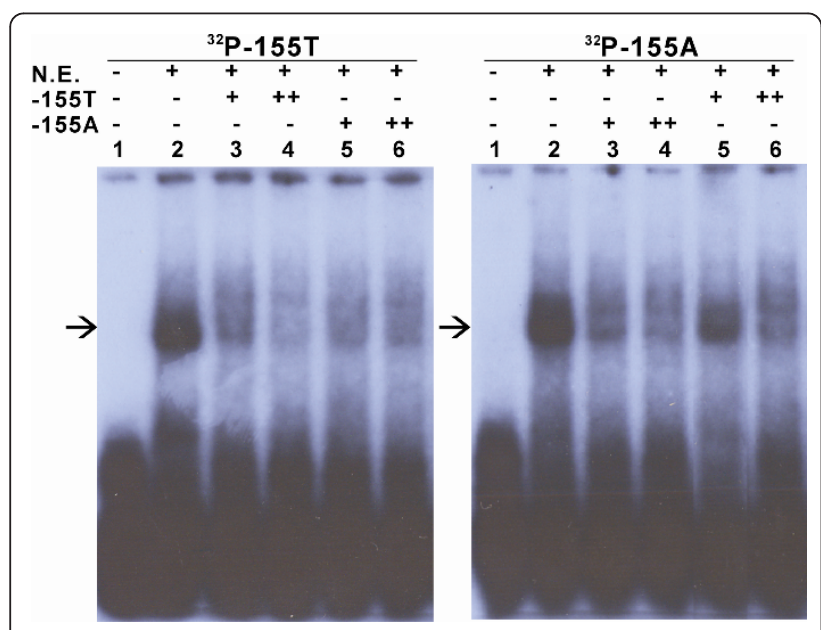

Figure 4 The $T>A$ transition at position -155 of the porcine $A P O E$ gene increases DNA-binding affinity of nuclear protein(s) in porcine fetal fibroblasts. Electrophoretic mobility shift assays were carried out as described in Materials and Methods. ProteinDNA complexes were separated on 5\% PAGE and exposed to X-ray film. In competition experiments (lanes 3-6), Nuclear extracts were preincubated in the absence (-) or 10-fold excess (+) or 50-fold excess $(++)$ of unlablled competitor before addition of the ${ }^{32} \mathrm{P}$ labelled probe. Binding complexes identified with the $-155 T$ probe and $-155 \mathrm{~A}$ probe were indicated with arrows.
-155A probe was largely eliminated by co-incubation with unlabelled $-155 \mathrm{~A}$ competitor (lanes 3, 4 of Figure $4 \mathrm{~B}$ ) or unlabelled 50-fold excess $-155 \mathrm{~T}$ probe (lane 6 of Figure 4B), whereas a conspicuous complex formation was observed in the presence of unlabelled 10-fold excess $-155 \mathrm{~T}$ competitor (lanes 5 of Figure 4B). The results indicated that $-155 \mathrm{~A}$ allele can greatly enhance the binding affinity of transcriptional factor(s).

\section{Discussion}

This study identified a functional SNP in the 5' regulatory region of porcine $A P O E$. The behaviours of the allelic forms of the reporter gene expression, real-time PCR and EMSA in our study strongly suggested that $-155 \mathrm{~T}>\mathrm{A}$ allelic differences of the $A P O E$ transcription may be a consequence of differential binding ability of transcriptional factors or differential transcriptional factors bound to a wild type or a mutation type present in cells.

To distinguish potentially functional SNPs from nonfunctional SNPs, we focused on cis-acting elements based on the suggestion of Knight [28] and used a predictive program http://www.genomatix.de[27]. The results indicated there were different transcription factors binding the cis-acting elements surrounding the -155 SNP (additional file 1 ). The $-155 \mathrm{~T}$ contains a CCCTCCC motif that is known as the SP1 binding site [29], and SP1 has been implicated for its function in regulating $\mathrm{AD}$-associated genes [30]. Meanwhile, the mutation at porcine APOE -155 site still had SP1 binding ability.

The existence of multiple transcription factors binding the -155 region was further reinforced by incubation of a -155T/A DNA probe with nuclear extracts from porcine fetal fibroblasts forming DNA-protein complexes as demonstrated by EMSA. Importantly, competition EMSA using excess unlabelled probes revealed a difference in the binding affinities of promoter alleles: excess -155A DNA cold probe effectively abolished complex formation, whereas 10-fold excess - $155 \mathrm{~T}$ DNA cold probe failed to prevent labelled -155A probe-protein complex formation. From the above results, we could consider that the $-155 \mathrm{~A}$ promoter had a significantly higher affinity for binding factors than that for the $-155 \mathrm{~T}$ promoter. Interestingly, for human APOE -491A $>\mathrm{T}$ mutation, the $-491 \mathrm{~A}$ displayed an increased affinity for human hepatic nuclear proteins [14], while the -491A showed an opposite trend for rat pheochromocytoma and human SK-N-SH neuroblastoma nuclear proteins [15].

It was demonstrated, in transfected cells, that the cloned promoter containing the $-155 \mathrm{~A}$ variant was significantly stronger than that of the corresponding $-155 \mathrm{~T}$ variant at driving luciferase expression (6.7-fold higher expression, $P<0.01)$. The cloned promoter in this 
research did not contain either of the other two identified polymorphic sites $(-440$ and +501$)$. The difference in transcription efficiency was confirmed in vivo, and APOE mRNA levels were 11 times higher in liver tissue from -155AA homozygous pigs than that in the tissue from -155TT homozygotes $(P<0.01)$. In the report of Maloney et al. [15], human $-491 \mathrm{~A}>\mathrm{T}$ variant interacted with $-219 \mathrm{G}>\mathrm{T}$ because both mutations altered the variety and binding affinity of transcription factors. However, the $-401 \mathrm{SNP}$ and +501SNP in porcine APOE were not expected to change the transcription factors, which implied that there may be no interactive effect between porcine APOE -155SNP and the other two SNPs.

All these data suggest that polymorphism at SNP-155 modulates transcription of the porcine $A P O E$ gene by affecting the ability of the $A P O E$ promoter to bind to trans-acting factors. It is notable that the $-155 \mathrm{~T}>\mathrm{A}$ substitution alters the CCCTCCC sequence to CCCACCC. The CACCC box is a well-described cis-acting transcription element that can serve as a binding site for widely distributed transcription-activating factors that act collaboratively with other regulatory proteins [31]. There are a larger family of zinc finger transcription factors bound to CACCC box [32]. Mutation of this box is thought to change binding and transactivation by transcription factors and therefore to decrease transcription levels [33-36].

Our results suggest that the $-155 \mathrm{~A}$ allele is associated with increased levels of $A P O E$ transcription in vivo. It seems probable that the $-155 \mathrm{~A}$ variant can elevate levels of apoE protein. We also report that the frequency of the -155AA genotypes is significantly under-represented, compared to -155TT and -155TA, in each of the four different pig populations analyzed. Although the explanation for this depletion is unknown, there are several considerations as follows.

Firstly, it was previously reported that apoE enhanced cell lipid homeostasis $[17,37]$ and could reduce the risk of heart disease [16,38]. In humans, the concentration of apoE in plasma or brain varies according to $A P O E$ genotype in the order E2 > E3 > E4 [37], and the E4 allele is an established risk factor for AD. The -491A allele of human $A P O E$ is also a risk factor for $\mathrm{AD}$, but this function is associated with higher levels of $A P O E$ transcription versus the $-491 \mathrm{~T}$ allele, and these effects are exerted independently of E4 [14]. In the experiments reported here we found that the $-155 \mathrm{~A}$ allele was associated with significantly increased transcription of porcine $A P O E$ both in transfected cells and hepatic tissue. Higher apoE concentration lead to increased cytotoxicity [39], thus $-155 \mathrm{~A}$ allele may be harmful to porcine survival.

Secondly, some recessive genes that terminate fetal development are known to be located on swine chromosome SSC6 between $S W 855$ and $S W 122$ [40], a region that includes the porcine $A P O E$ gene $[22,40]$. The affected gene(s) in the homozygous state can prevent embryo development after 9 days post-coitus when the spherical embryo grows to the filamentous form, leading to embryonic death due to implantation failure [40]. This suggests that under-representation of -155AA could be a consequence of linkage disequilibrium between porcine $A P O E$ and other genes in the vicinity.

\section{Conclusions}

We have identified a functional SNP in the regulatory region of the porcine $A P O E$ gene that was associated with altered interactions with DNA-binding factors, marked differences in the activity of the $A P O E$ promoter and levels of $A P O E$ mRNA in vivo.

\section{Methods}

\section{Screening for porcine APOE 5 ' regulatory SNPs}

All animal procedures were performed according to protocols approved by the Biological Studies Animal Care and Use Committee of Guangdong Province, China. Ear tissues of Landrace, Yorkshire, Chinese indigenous breed Lantang and Dahuabai pigs were used for genomic DNA isolation according to Sambrook and Russell [41]. Primers (Table 2) for three overlapping segments were designed with Primer Primer 5.0 according to porcine APOE sequence (GenBank: U70240.1). The PCR products were sequenced and genotyped.

\section{Real-time quantitative PCR}

Total RNA was extracted from the hepatic tissue of adult Dahuabai pig (-155TT, -155TA, -155AA, 6 animals of each of the three genotypes) with TRIzol reagent (Invitrogen). QRT-PCR analysis was performed using the ABI 7500 system (Applied Biosystems) (primers: 5'-CGCAGGATGCCGGACAGA-3' and 5'-CCTCCTGCACTTGGTCAGACA-3'). The gene expression levels were qualified relative to the expression of $\beta$-actin by the comparative $C_{T}$ method [42].

\section{Plasmid constructions}

The DNA segment spanning the -268 to -11 region of porcine $A P O E$ and containing either the $-155 \mathrm{~T}$ or $-155 \mathrm{~A}$ variants was amplified with the primers 5 CACGCGTAGTGGCATGGAGAAA-3' and 5'- ACTCGAGACTCCTCCAGAACT -3 ', thereby creating the restriction sites of $M l u \mathrm{I}$ and $\mathrm{XhoI}$ (underlined). Following restriction enzyme digestion the PCR products were inserted to vector pGL3-basic (Promega). The integrity of cloned sequences was confirmed by sequencing.

\section{Transient transfection assays}

Porcine fetal fibroblast cell line was established as described previously [43]. Cells $\left(1.5 \times 10^{6}\right.$ per well $)$ were 
Table 2 Primers for SNP detection in the porcine APOE 5'-regulatory region

\begin{tabular}{cccc}
\hline Primers & \multicolumn{1}{c}{ Sequences } & Annealing temperature & PCR product length \\
\hline P1 & Upstream: 5'-TCGAGAGGGAGTGAGGGTTAAAA-3' & $538 \mathrm{bp}$ \\
& Downstream: 5'-AGGAGCAGGACCAGAAGG-3' & $59^{\circ} \mathrm{C}$ & $455 \mathrm{bp}$ \\
P2 & Upstream: 5'-GGCCTTCTGGTCCTGCTCCT-3' & $61^{\circ} \mathrm{C}$ & $728 \mathrm{bp}$ \\
& Downstream: 5'-AACTCCTGCCTCGGTGGTGG-3' & & $60^{\circ} \mathrm{C}$ \\
& Upstream: 5'-CACCGAGGCAGGAGTTGG-3' & & \\
\hline
\end{tabular}

seeded into 96-well plates and grown to $80-90 \%$ confluence, and transfected with $A P O E$ promoter/firefly luciferase reporter plasmids by Lipofectamine 2000 transfection reagent (Invitrogen). To control for transfection efficiency, cells were co-transfected with $2 \mathrm{ng}$ of Renilla luciferase reporter plasmid (Promega). After 48 $\mathrm{h}$ of transfection, cells were lysed and assayed for promoter activity using the dual luciferase reporter assay system. Firefly luciferase activity was expressed relative to Renilla luciferase activity.

\section{Electrophoretic mobility shift assays}

Nuclear proteins were extracted from porcine fetal fibroblast cells cultured at third passage (Nuclear Extract Kit, Active Motif). The sequences used for EMSAs were 5'-CCCCTCCCCC(프/A)CCCTGCTGTGTG-3' surrounding the -155 site. The oligonucleotides were 5'labeled with $\left[\gamma_{-}{ }^{32} \mathrm{P}\right]$-ATP using a Megalabel DNA 5'labelling Kit according to the specifications of the manufacturer (Takara). The 5'-labelled probes used in subsequent experiments were double stranded.

The binding mixture included $0.5 \mu \mathrm{g}$ poly $(\mathrm{dI}-\mathrm{dC})$ (Amersham Biosciences), $2 \mu$ l of $5 \times$ gel-shift binding buffer, $2 \mu \mathrm{g}$ of nuclear extract. The mixture was maintained at room temperature for $10 \mathrm{~min}, 2 \mu \mathrm{l}$ of radiolabelled oligonucleotide probe was added, and incubation was kept for a further $20 \mathrm{~min}$ at room temperature in the presence or absence of a 10- to 50-fold molar excess of unlabelled probes. DNA-protein complexes were fractionated by electrophoresis on $5 \%$ non-denaturating polyacrylamide gels.

\section{Data analysis}

For continuous data, comparisons of two means employed independent $t$ tests, $q$ values were calculated for comparisons of three means. Genotype frequencies were analyzed with probit models [44].

\section{Additional material}

Additional file 1: Transcriptional factors surrounding -155SNP predicted by MatInspector.

\section{Abbreviations}

APOE: apoliprotein E gene; apoE: apoliprotein E; EMSA: electrophoretic mobility shift assays; SNP: single nucleotide polymorphism; AD: Alzheimer's disease; qRT-PCR: quantitative real-time polymerase chain reaction.

\section{Acknowledgements}

We wish to thank Changli Wu and Liangliang Wang for their help in PCR and animal genotyping.

The Work was supported by National Science Foundation of China (30771545, 30871781), the 863 Project of China (2007AA10Z161, 2008AA10Z135) and the earmarked fund for Modern Agro-industry Technology Research System (CARS-36).

\section{Author details}

'Guangdong Provincial Key Lab of Agroanimal Genomics and Molecular Breeding, College of Animal Science, South China Agricultural University, Guangzhou 510642, Guangdong, PR China. 'Department of Animal Genetics, Breeding and Reproduction, College of Animal Science, South China Agricultural University, Guangzhou 510642, Guangdong, PR China. ${ }^{3}$ Laboratory of Animal Physiology and Biochemistry, College of Animal Science, South China Agricultural University, Guangzhou 510642, Guangdong, PR China. ${ }^{4}$ College of Life Sciences, Zhongkai University of Agriculture and Engineering, Guangzhou 510225, Guangdong, PR China.

\section{Authors' contributions}

SL conceived and designed the study, performed the EMSAs, designed PCR primers and wrote the paper. HZ designed the study, performed the QRT-PCR, and genotyped the animals, analyzed the data and wrote the paper. PG cultured porcine fetal fibroblast cells, constructed the plasmids and performed transient transfection assays. ZC extracted DNA and RNA, and performed animal genotyping. CW extracted DNA and RNA, and performed qRT-PCR experiments. JL designed the study, supervised the experiments and wrote the paper. All authors read and approved the final manuscript.

Received: 10 May 2010 Accepted: 9 May 2011 Published: 9 May 2011

\section{References}

1. Mahley R, Huang Y: Apolipoprotein E: from atherosclerosis to Alzheimer's disease and beyond. Curr Opin Lipidol 1999, 10(3):207-217.

2. Kim J, Basak JM, Holtzman DM: The role of apolipoprotein E in Alzheimer's disease. Neuron 2009, 63(3):287-303.

3. Mahley RW: Apolipoprotein E: cholesterol transport protein with expanding role in cell biology. Science 1988, 240(4852):622-630.

4. Rogers JT, Weeber EJ: Reelin and apoE actions on signal transduction, synaptic function and memory formation. Neuron Glia Biol 2008, 4(3):259-270.

5. Utermann G, Langenbeck U, Beisiegel U, Weber W: Genetics of the apolipoprotein E system in man. Am J Hum Genet 1980, 32(3):339-347.

6. Heeren J, Beisiegel U, Grewal T: Apolipoprotein E recycling: implications for dyslipidemia and atherosclerosis. Arterioscler Thromb Vasc Biol 2006, 26(3):442-448.

7. Kypreos KE, Karagiannides I, Fotiadou EH, Karavia EA, Brinkmeier MS Giakoumi SM, Tsompanidi EM: Mechanisms of obesity and related pathologies: role of apolipoprotein $E$ in the development of obesity. FEBS J 2009, 276(20):5720-5728. 
8. Lehtimäki T, Pirttilä T, Mehta PD, Wisniewski HM, Frey H, Nikkari T: Apolipoprotein $\mathrm{E}$ (apoE) polymorphism and its influence on ApoE concentrations in the cerebrospinal fluid in Finnish patients with Alzheimer's disease. Hum Genet 1995, 95(1):39.

9. Iveskoski E, Perola M, Lehtimaki T, Laippala P, Savolainen V, Pajarinen J, Penttila A, Lalu KH, Mannikko A, Liesto KK, Koivula T, Karhunen PJ: Agedependent association of apolipoprotein E genotype with coronary and aortic atherosclerosis in middle-aged men: an autopsy study. Circulation 1999, 100(6):608-613.

10. Nieminen $T$, Kähönen $M$, Viiri L, Grönroos $P$, Lehtimäki T: Pharmacogenetics of apolipoprotein E gene during lipid-lowering. Pharmacogenomics 2008, 9(10):1486-1745

11. Viiri LE, Loimaala A, Nenonen A, Islam S, Vuori I, Karhunen PJ, Lehtimaki T: The association of the apolipoprotein E gene promoter polymorphisms and haplotypes with serum lipid and lipoprotein concentrations. Atherosclerosis 2005, 179(1):161-167.

12. Artiga MJ, Bullido MJ, Sastre I, Recuero M, Garcia MA, Aldudo J, Vazquez J, Valdivieso F: Allelic polymorphisms in the transcriptional regulatory region of apolipoprotein E gene. Febs Lett 1998, 421(2):105-108.

13. Viiri LE, Viiri KM, Ilveskoski E, Huhtala H, Maki M, Tienari PJ, Perola M, Lehtimaki T, Karhunen PJ: Interactions of functional apolipoprotein $E$ gene promoter polymorphisms with smoking on aortic atherosclerosis. Circ Cardiovasc Genet 2008, 1(2):107-116.

14. Bullido MJ, Artiga MJ, Recuero M, Sastre I, Carcía MA, Alaudo J, Lendon C, Han SW, Morris JC, Frank A, Várquez J, Goate A, Valdivivso F: A polymorphism in the regulatory region of APOE associated with risk for Alzheimer's dementia. Nat Genet 1998, 18.

15. Maloney B, Ge YW, Petersen RC, Hardy J, Rogers JT, Perez-Tur J, Lahiri DK: Functional characterization of three single-nucleotide polymorphisms present in the human APOE promoter sequence: Differential effects in neuronal cells and on DNA-protein interactions. Am J Med Genet B Neuropsychiatr Genet 2010, 153B(1):185-201.

16. Lambert JC, Brousseau T, Defosse V, Evans A, Arveiler D, Ruidavets JB, Haas B, Cambou JP, Luc G, Ducimetiere P, Cambien F, Chartier-Harlin MC, Amouyel $P$ : Independent association of an APOE gene promoter polymorphism with increased risk of myocardial infarction and decreased APOE plasma concentrations-the ECTIM study. Hum Mol Genet 2000, 9(1):57-61.

17. Viiri LE, Raitakari OT, Huhtala H, Kahonen M, Rontu R, Juonala M, HutriKahonen N, Marniemi J, Viikari JS, Karhunen PJ, Lehtimaki T: Relations of APOE promoter polymorphisms to LDL cholesterol and markers of subclinical atherosclerosis in young adults. J Lipid Res 2006, 47(6):1298-1306.

18. Ward H, Mitrou PN, Bowman R, Luben R, Wareham NJ, Khaw KT, Bingham S: APOE genotype, lipids, and coronary heart disease risk: a prospective population study. Arch Intern Med 2009, 169(15):1424-1429

19. Tycko B, Lee $J H$, Ciappa A, Saxena A, Li CM, Feng L, Arriaga A, Stern Y, Lantigua R, Shachter N, Mayeux R: APOE and APOC1 promoter polymorphisms and the risk of Alzheimer disease in African American and Caribbean Hispanic individuals. Arch Neurol 2004, 61(9):1434-1439.

20. Thome J, Gewirtz JC, Sakai N, Zachariou V, Retz-Junginger P, Retz W, Duman RS, Rosler M: Polymorphisms of the human apolipoprotein $E$ promoter and bleomycin hydrolase gene: risk factors for Alzheimer's dementia? Neurosci Lett 1999, 274(1):37-40.

21. Zurutuza L, Verpillat $P$, Raux G, Hannequin D, Puel M, Belliard S, Michon A, Pothin Y, Camuzat A, Penet C, Martin C, Brice A, Campion D, ClergetDarpoux F, Frebourg T: APOE promoter polymorphisms do not confer independent risk for Alzheimer's disease in a French population. Eur J Hum Genet 2000, 8(9):713-716.

22. Bosak N, Faraut T, Mikawa S, Uenishi H, Kiuchi S, Hiraiwa H, Hayashi T, Yasue $\mathrm{H}$ : Construction of a high-resolution comparative gene map between swine chromosome region $6 q 11->q 21$ and human chromosome 19 q-arm by RH mapping of 51 genes. Cytogenet Genome Res 2003, 102(1-4):109-115.

23. Kurył J: Phenotyping of porcine Apoliprotein E using isoelectric focusing and localization of the apoE gene within the Halothane-susceptibility linkage group. Biochem Genet 1999, 37(9-10):281-287.

24. Ramsoondar JJ, Rucker EB, Vasquez JC, Gallagher DS, Grimm DR, Lunney JK, Schook LB, Piedrahita JA: Isolation and genetic characterization of the porcine apolipoprotein E gene. Anim Genet 1998, 29(1):43-47.
25. Brzozowska A, Grimholt U, Kulseth MA, Wold I, Rogne S: The sequence of porcine apolipoprotein E (APOE) cDNA. DNA Seq 1993, 4(3):207-210.

26. Fan B, Onteru SK, Mote BE, Serenius T, Stalder KJ, Rothschild MF: Largescale association study for structural soundness and leg locomotion traits in the pig. Genet Sel Evol 2009, 41:14.

27. Cartharius K, Frech K, Grote K, Klocke B, Haltmeier M, Klingenhoff A, Frisch M, Bayerlein M, Werner T: MatInspector and beyond: promoter analysis based on transcription factor binding sites. Bioinformatics 2005, 21(13):2933-2942.

28. Knight JC: Regulatory polymorphisms underlying complex disease traits. J Mol Med 2005, 83(2):97-109.

29. Bockamp EO, Fordham JL, Gottgens B, Murrell AM, Sanchez MJ, Green AR: Transcriptional regulation of the stem cell leukemia gene by PU.1 and Elf-1. J Biol Chem 1998, 273(44):29032-29042.

30. Dosunmu R, Wu J, Adwan L, Maloney B, Basha MR, McPherson CA, Harry GJ, Rice DC, Zawia NH, Lahiri DK: Lifespan profiles of Alzheimer's diseaseassociated genes and products in monkeys and mice. J Alzheimers Dis 2009, 18(1):211-230.

31. Hartzog G, Myers R: Discrimination among potential activators of the beta-globin CACCC element by correlation of binding and transcriptional properties. Mol Cell Biol 1993, 13(1):44-56.

32. Wang $X$, Talamantez JL, Adamo ML: A CACCC box in the proximal exon 2 promoter of the rat insulin-like growth factor I gene is required for basal promoter activity. Endocrinology 1998, 139(3):1054-1066.

33. Kulozik AE, Bellan-Koch A, Bail S, Kohne E, Kleihauer E: Thalassemia intermedia: moderate reduction of beta globin gene transcriptional activity by a novel mutation of the proximal CACCC promoter element. Blood 1991, 77(9):2054-2058.

34. Faustino $P$, Lavinha J, Marini MG, Moi P: beta-Thalassemia mutation at $-90 C->T$ impairs the interaction of the proximal CACCC box with both erythroid and nonerythroid factors. Blood 1996, 88(8):3248-3249.

35. Feng WC, Southwood CM, Bieker JJ: Analyses of beta-thalassemia mutant DNA interactions with erythroid Kruppel-like factor (EKLF), an erythroid cell-specific transcription factor. J Biol Chem 1994, 269(2):1493-1500.

36. Moi P, Faa V, Marini MG, Asunis I, Ibba G, Cao A, Rosatelli MC: A novel silent beta-thalassemia mutation in the distal CACCC box affects the binding and responsiveness to EKLF. Br J Haematol 2004, 126(6):881-884

37. Poirier J: Apolipoprotein $\mathrm{E}$, cholesterol transport and synthesis in sporadic Alzheimer's disease. Neurobiol Aging 2005, 26(3):355-361.

38. Hirashiki A, Yamada Y, Murase $Y$, Suzuki Y, Kataoka H, Morimoto Y, Tajika T, Murohara T, Yokota M: Association of gene polymorphisms with coronary artery disease in low- or high-risk subjects defined by conventional risk factors. J Am Coll Cardiol 2003, 42(8):1429-1437.

39. Miyata M, Smith JD: Apolipoprotein E allele-specific antioxidant activity and effects on cytotoxicity by oxidative insults and beta-amyloid peptides. Nat Genet 1996, 14(1):55-61

40. Mikawa S, Kishi H, Ogawa H, Iga K, Uenishi $H$, Yasue $H$ : Analysis of recessive lethality on swine chromosome 6 in a Gottingen miniature resource family. Anim Genet 2005, 36(5):376-380.

41. Sambrook J, Russell DW: Molecular Cloning: A Laboratory Manual. NY: Cold Spring Harbor Laboratory; 32001.

42. Schmittgen TD, Livak KJ: Analyzing real-time PCR data by the comparative CT method. Nature Protocols 2008, 3(6):1101-1108

43. Boquest AC, Day BN, Prather RS: Flow cytometric cell cycle analysis of cultured porcine fetal fibroblast cells. Biol Reprod 1999, 60(4):1013-1019.

44. Kaps M, Lamberson W: Biostatistics for animal science. Wallingford: CABI Publishing; 2004.

doi:10.1186/1471-2156-12-40

Cite this article as: Li et al:: A functional mutation at position -155 in porcine APOE promoter affects gene expression. BMC Genetics 2011 12:40. 